\title{
Rola kompetencji poznawczych w demokratycznych systemach politycznych
}

\begin{abstract}
Abstrakt: Wychodząc od normatywnego ideału demokracji, ugruntowanego w inkluzywnym rozumieniu podmiotu demokracji, autor twierdzi, że w większości koncepcji demokracji kompetencje poznawcze są postrzegane jako podstawowy wymóg upoważniający do udziału w sprawowaniu władzy politycznej. Współczesna debata nad właściwym rozumieniem demokracji koncentruje się na próbach rozstrzygnięcia dylematu między ideą szerokiego uczestnictwa ludu w sprawowaniu władzy a ideałem deliberacyjnym, który zakłada, że władza w tych systemach winna być powierzona wyłącznie osobom o odpowiednich kompetencjach poznawczych. Autor analizuje główne elementy stanowisk kognitokratycznych i wskazuje na potencjalne zagrożenia wynikające z przypisywania kompetencjom poznawczym wyróżnionej roli. Stanowiska tego typu, zarówno w wersji uniwersalistycznej, jak i elitarnej, są według autora obciążone błędem kognitokratycznym. W opozycji do nich autor argumentuje na rzecz tezy o podstawowej roli umiejętności politycznej w systemach demokratycznych. Wskazuje również, że punktem wyjścia do rozważań nad znaczeniem tego pojęcia winien być normatywny ideał demokracji inkluzywnej, zakładający powszechność zdolności do kształtowania umiejętności politycznej oraz przekonanie, że owa zdolność może ulegać aktualizacji w samym procesie aktywności politycznej.
\end{abstract}

Słowa kluczowe: demokracja, wiedza, władza, epistokracja, umiejętność polityczna

\section{Wprowadzenie}

$\mathbf{N}$ ormatywnym celem demokracji jest stworzenie możliwości udziału w rządzeniu wspólnoty politycznej przez całe społeczeństwo wchodzące w jej skład. Demokracja rozumiana $\mathrm{w}$ ten sposób ma za zadanie zrównanie wszystkich członów społeczeństwa w prawach politycznych. Zdefiniowany w ten sposób cel jest konsekwencją inkluzywnego rozumienia podmiotu demokracji. Na mocy tej definicji podmiotowi demokracji przysługuje bezpośredni udział w sprawowaniu władzy. Idea zarządzania wspólnotą polityczną za pomocą podejmowania decyzji przez wszystkich obywateli, w której lud jest jednocześnie suwerenem i poddanym, można więc uznać za typ idealny demokracji. W praktyce politycznej taka koncepcja znana m.in. jest z przemówienia Abrahama Lincolna, który definiował demokrację jako „rządy ludu sprawowane przez lud dla ludu" (Lincoln, 1998, s. 267); jest ona także podstawą Konstytucji Republiki Francji, której artykuł 2 głosi: Son principe est: gouvernement du peuple, par le peuple et pour le people.

Prostota tej koncepcji demokracji jest zniewalająca, a zarazem zwodnicza, nasuwa bowiem ona liczne, dobrze zdiagnozowane problemy. Najważniejszy z nich wiąże się z wieloznacznością samego pojęcia ludu. Przez większość dziejów lud był pojmowany jako ludzka masa odmienna od klasy średniej, klasy posiadaczy oraz arystokracji i nie był traktowany jako część tkanki społecznej, a z tej racji nie był postrzegany jako 
uprawniony do sprawowania władzy i nie miał w niej udziału. Pierwszym teoretykiem wykluczenia z polityki tak rozumianego „ludu” był Platon. W interpretacji Leo Straussa cechy duszy niższych kast idealnej politei uniemożliwiają im poznanie idei sprawiedliwości i z tej racji „tęsknią do tyranii, tj. skrajnej niesprawiedliwości” (Strauss, 1987, s. 47). Problem ten pojawił się w refleksji filozofii znacznie wcześniej, mianowicie u Heraklita. Swoją potencjalnie uniwersalistyczną koncepcję racjonalności myśliciel ten ograniczył za pomocą twierdzenia, zgodnie z którym u większości ludzi znajduje się ona w stanie uśpienia i dlatego nie władają w pełni rozumem, a w konsekwencji słowem i czynem działają wbrew prawu natury, co pociąga negatywne konsekwencje dla nich i dla społeczności (Gajda, 1986, s. 143). Jeszcze wcześniejszym świadectwem problematyczności postulatu powszechnego udziału ludu w sprawowaniu władzy jest opinia Anacharsysa, współczesnego Solonowi, który wziąwszy udział jako obserwator w ateńskim demokratycznym Zgromadzeniu Ludowym miał zauważyć, że w greckiej polis mowy wygłaszają mędrcy, ale decyzje podejmuje gromada głupców i nieuków. Można więc pokusić się o hipotezę, że opozycja między stanowiskiem uznającym prawo do udziału we władzy wszystkim członkom wspólnoty politycznej a stanowiskiem, zgodnie z którym warunkiem jej sprawowania jest posiadanie określonych kompetencji, wśród których kompetencje poznawcze odgrywają rolę szczególnie ważną, pojawiła się już wraz z narodzinami demokracji.

Mimo demokratyzacji sporej liczby państw na świecie, pojmowanie ludu jako masy niezdolnej do udziału w polityce nadal jest przyjmowane, implicite lub explicite, przez liczne koncepcje polityki, zwłaszcza o charakterze konserwatywnym i liberalnym. Cechą obecnych systemów demokratycznych jest więc napięcie między uporządkowanym, stabilnym ciałem społecznym, w którym każdy ma swoje miejsce, a „częścią, która nie jest częścią", tj. elementem podważającym istniejący porządek (Žižek, 2001, s. 89-90). Tą częścią jest właśnie lud, demos, który, choć współczesnym demokracjom użyczył imienia, nie w pełni znajduje w nich miejsce dla siebie. Albowiem realia współczesnych demokracji bardziej zbliżają ją do idei zarządzania tłumem aniżeli do wyżej wskazanego, inkluzywnego typu idealnego demokratyczności.

Są po temu istotne powody. Koncepcja demokracji jako rządów ludu przez lud dla ludu ma bowiem dwie zasadnicze wady. Po pierwsze, lud nie może w trwały i bezpośredni sposób rządzić całą wspólnotą. Z tej racji wyłonił się system demokracji przedstawicielskiej. Na mocy tego systemu wszyscy obywatele dokonują wyborów swoich przedstawicieli do sprawowania władzy we wspólnocie politycznej, przy czym ich zadaniem nie jest reprezentowanie partykularnych interesów swoich wyborców, lecz kierowanie dobrem całości społeczeństwa. Tak głosi zasada sformułowana po raz pierwszy przez Emanuela-Josepha Sieyèsa w pamflecie Qu'est-ce que le tiers-état (1789), która przybrała nazwę „mandatu wolnego” (Bobbio, 1998, s. 23). Najbardziej znanym przeciwnikiem demokracji przedstawicielskiej był Jean-Jacques Rousseau, który rozumiał demokrację w sposób zbliżony do powyżej przytoczonego typu idealnego. Sądził bowiem, że z chwilą, gdy lud sprawuje swoją władzę za pośrednictwem wyboru swoich reprezentantów, pozbawia się wolności: ,[Z] chwilą, gdy lud wprowadza u siebie przedstawicieli, przestaje być wolnym, przestaje istnieć" (Rousseau, 2002, s. 76).

Drugim zasadniczym problemem wiążącym się z powyższym typem idealnym demokracji jest to, że powierzenie sterów państwa rządowi wyłonionemu w powszechnym 
plebiscycie, bez dodatkowych mechanizmów kontrolnych nad nim, prowadzi do niebezpiecznego zjawiska tyranii większości. Problem ten jednak nie polega tylko na niebezpieczeństwie tyranii większości, ale także i na tym, w jaki sposób można uzasadnić prawomocność owych mechanizmów kontrolnych nad demokracją. Przyjmuje się bowiem zazwyczaj, że demokracja nie wymaga uprawomocnienia: demokracja jest źródłem i narzędziem udzielającym uprawomocnienia sobie samej. Jeżeli tak jest, to jedynym możliwym narzędziem uprawomocnienia mechanizmów kontrolnych nad demokracją jest sama demokracja. To wskazuje na teoretyczny problem samozwrotności, którego można uniknąć za pomocą uznania, że demokracja musi podlegać normatywnym zasadom sformułowanym poza samym mechanizmem demokratycznym. Próby sformułowania pozademokratycznych podstaw demokracji są jednak ryzykowne, albowiem nieuchronnie generują kontrowersje ideologiczne i aksjologiczne.

\section{Nadużycia demokracji}

Kwestia ta pojawia się także na gruncie praktyki politycznej. W coraz większej liczbie krajów władze sprawują ugrupowania, formacje lub jednostki, które uzyskują swój mandat do sprawowania władzy pochodzący z powszechnego wyboru, a więc demokratyczny. Jednakże cykliczne wybory urządzały i urządzają reżimy polityczne rozmaitego autoramentu, także te, które nie mają nic wspólnego z demokracją. Czynią tak nawet systemy despotyczne, które potrzebują sztafażu demokratycznego wyboru jako legitymacji swojej władzy. Niekiedy podmioty polityczne, odniósłszy sukces wyborczy, w swoim praktycznym działaniu dokonują demontażu instytucji demokratycznych. Usprawiedliwieniem dla współcześnie przebiegającego demontażu demokracji jest nic innego, jak demokratyczne przyzwolenie i aprobata elektoratów: działania antydemokratyczne mają demokratyczne uprawomocnienie. To klasyczny przypadek paradoksu demokracji, który jako pierwszy nazwał i zdiagnozował Karl Popper (1993, t. I, s. 144-146). Demokracje upadają nie tyko wskutek zamachów; upadają także wskutek demokratycznego głosowania.

Jak do tego dochodzi? Problemem jest nie tyle mechanika demokratycznych wyborów, lecz fakt, że mechanika demokratyczna daje się wykorzystywać do różnych celów. Aby wskazać możliwie najprościej, w jaki sposób się to odbywa, wystarczy zauważyć, że demokratyczna mechanika wyborcza była wykorzystywana, z jednej strony, przez rodzinę miliarderów Roberta i Rebekę Mercer, którzy przyczynili się do wyboru Donalda Trumpa na stanowisko prezydenta USA (Swenson, 2018), a zarazem, z drugiej strony, przez innego miliardera, George'a Sorosa, który starał się wpływać, z różnym powodzeniem, na werdykt wyborczy zarówno w USA, jak i w innych krajach. To oznacza, że mimo różnych mechanizmów kontrolnych i równoważących, demokratyczny werdykt można sobie kupić. Aby zrozumieć, że nie w demokracji tkwi problem, wystarczy postawić pytanie, na czym polega różnica między miliarderami Mercer a miliarderem Sorosem? Odpowiedź brzmi: różnica tkwi w wartościach symbolizowanych przez te przykładowe postacie. Przez kryzys demokracji należy zatem rozumieć kryzys społecznie wyznawanych wartości.

Fakt ten nadaje niepokojącą wiarygodność dylematowi Böckenfördego, według którego „wolne [freiheitlich] zeświecczone państwo żyje według wymogów, których samo 
nie jest w stanie zagwarantować. Jako wolne państwo może przetrwać tylko wówczas, jeżeli wolność, jaką nadaje ono swoim obywatelom, czerpie pewne regulacje z zewnątrz, zarówno z moralnej substancji jednostek, jak i z pewnej homogeniczności społeczeństwa w ogóle. Z drugiej strony jednak, nie jest ono w stanie samo z siebie wytworzyć owych tych wewnętrznych sił regulacyjnych, to znaczy nie może tego uczynić za pomocą jego własnych środków, jak prawny przymus lub autorytatywny nakaz. Gdyby tak postępowało, wyzbyłoby się swojego wolnego charakteru i cofnęłoby się w świecki sposób do roszczeń totalizujących, z których kiedyś, w okresie wojen konfesyjnych, wskazywało drogę wyjścia" (Böckenförde, 1976, s. 60). Uznanie tego dylematu nie oznacza naturalnie aprobaty dla rozwiązań proponowanych przez tego myśliciela.

Liczne próby teoretycznego zrozumienia normatywnych podstaw demokracji oraz możliwych sposobów ich realizacji w realiach życia politycznego doprowadziły do sformułowania wielu alternatywnych modeli. „Demokracja” oznacza bowiem, z jednej strony, rozmaicie definiowane cele systemu politycznego oraz, z drugiej, rozmaite modele sprawowania władzy. Wśród metod demokratycznego sprawowania władzy wyróżnia się modele demokracji (i) bezpośredniej, (ii) przedstawicielskiej, (iii) równowagi opartej na idei wzajemnej kontroli instytucji demokratycznego państwa (checks and balances), (iv) uczestnictwa, (v) agonistycznej, (iv) nieliberalnej oraz inne. Istotnym elementem polityki demokratycznej jest idea jawności życia politycznego oraz odpowiedzialność za podejmowane decyzje.

\section{Dysfunkcje demokracji}

Według obecnie formułowanych diagnoz systemy demokratycznego sprawowania władzy są podatne na kilka typów schorzeń. Należy do nich zanik podmiotowości indywidualnej i zbiorowej, wynikający z braku umiejętności politycznej, niezdolności do rozumienia swoich interesów, edukacji i kultury politycznej. Nie mniejszym problemem jest społeczne zróżnicowanie materialne, które prowadzi do zaburzenia równowagi społecznej wskutek nierówności społecznych i woli rewanżu na sprawcach swojej kondycji przez nieuprzywilejowaną większość. Trwałym elementem systemów demokratycznych jest populizm polegający na pozyskiwaniu wyborczego poparcia za pomocą perswazyjnej retoryki, czczych obietnic i wzbudzenia poczucia zagrożenia. Populizm żeruje na skłonności ludu do ulegania stadnym instynktom. Wreszcie dążności autorytarne, które w demokracji wynikają ze zniecierpliwienia żmudnym procesem podejmowania decyzji oraz koniecznością zawierania kompromisów, które okazują się niezadowalające dla nikogo. To, co przytacza się jako przyczyny kryzysu demokracji, samo jest skutkiem głębszych procesów. Pierwszym z nich jest systemowa immoralizacja polityki. Dawne przekonanie o tym, że „cnoty obywatelskie są jedynym fundamentem republik” (Lasch, 1997, s. 96) zostało zastąpione ideą, że właściwy system konstytucyjnych mechanizmów instytucjonalnych, kontrolnych i równoważących sprawi, że nawet „złemu człowiekowi będzie się opłacać działanie na rzecz dla dobra publicznego” (ibid.).

Tu dochodzimy do sedna problemu. Jeżeli powstają instytucje, których zadaniem jest dbanie o moralność jednostki, to ona sama czuje się zwolniona z obowiązku dyscyplinowania samej siebie. Człowiek postrzegający instytucje publiczne jako mechanizmy przymu- 
szające go do przyzwoitości, traci wewnętrzną zdolność do samoistnego stawiania sobie wymogów moralnych. Traci tym samym moralną zdolność do kultywowania cech i cnót obywatelskich. Indywidualne wewnętrzne sumienie ulega zastąpieniu przez zewnętrzną, formalną kontrolę. Właściwą przyczyną współczesnego kryzysu polityki jest więc zanik podmiotowości i aktywności obywatelskiej oraz rezygnacja z moralnej odpowiedzialności za własne losy, swoje bezpośrednie otoczenie i za wspólnotę polityczną. Mimo tego, trwanie systemów państwowych jest możliwe dlatego, że możliwe jest przekazanie troski o siebie i społeczeństwo na instytucje i mechanizmy zastępcze. Autentyczna aktywność polityczna uległa procesowi formalizacji obywatelstwa, zaś interaktywne uczestnictwo w procesie demokratycznym przeobraża się w bierność. $Z$ tych powodów biurokratyczne instytucje demokratyczne przeobraziły się w dekoracje demokracji.

Proces przekształcania się interaktywności obywatelskiej w pasywność, odpowiedzialny za fasadowość obecnej demokracji, jest wpisany w demokrację przedstawicielską. Jest on doskonale widoczny w modelu pluralistyczno-elitarnym Josepha Schumpetera czy poliarchicznym modelu Roberta Dahla, które są dominującą obecnie formą demokracji, a w istocie jest przez te modele wzmacniany. Według tych modeli, elity polityczne, wyłonione za pomocą partii politycznych, formułują odmienne projekty polityczne, które proponują obywatelom jako przedmiot powszechnego wyboru. Władza przypada rzecznikom tego projektu, który uzyskuje większość głosów wyborczych.

Sama idea tak skonstruowanej demokracji przedstawicielskiej polega na budowie mechanizmów zastępczości lub interpasywności, dzięki którym jednostki delegują swoją wolę na inne osoby, one zaś mają realizować jej cele za nią i w jej imieniu. Innymi słowy, wybierają swojego przedstawiciela, aby on za nich zadbał o ich interesy (Interpasywność to termin Roberta Pfallera, spopularyzowany przez S. Žižka; Žižek, 2001, s. 175; Chmielewski, 2005, s. 250-252). W modelu pluralistyczno-elitarnym jednostki delegują nawet zadanie myślenia o wspólnocie politycznej na elity je reprezentujące.

Odpolitycznienie ludu jest zaczynem autorytaryzmu. Psychologiczne skłonności ku autorytaryzmowi są zrozumiałe, ugruntowane i wzmacniane wskutek samej struktury demokracji przedstawicielskiej. Przedstawiciel, na którego przekazujemy zadanie troski o wspólnotę polityczną, jest tym samym obdarzany autorytetem, z którego sami rezygnujemy. Mechanizm zastępczości prowadzi do despotyzacji polityki. Zjawisko to jest widoczne zarówno w relacji ludu do władz państwowych, jak i zwłaszcza na płaszczyźnie samorządności lokalnej. Zwyrodnienie samorządności lokalnej w lokalne despotyzmy jest najdobitniejszym świadectwem wycofania się ludu z polityki, a więc z wypełniania obowiązków obywatelskich.

Towarzyszy temu także zjawisko demokracji wykluczającej. W takim systemie elity sprawujące władzę wskazują pewne grupy ludzi jako niepełnoprawnych członków społeczeństwa i pozbawiają ich pełni praw obywatelskich. Wykluczenie może być umocowane na bazie lokalnej kultury politycznej, obyczajowości pozapolitycznej lub wręcz umocowane w prawie. Np. osoby o pochodzeniu etnicznym odmiennym od dominującego w danej wspólnocie politycznej (ludność kolorowa, Żydzi, Rohingya), kobiety, osoby innego wyznania (muzułmanie) lub o odmiennych preferencjach seksualnych, są wykluczane na mocy obyczajów i panującej kultury politycznej. Takie wykluczenie często zyskuje aprobatę większości, ponieważ ułatwia dostęp do władzy tym, których wykluczenie nie dotyka. 
Zjawisko interpasywności prowadzi do innych przejawów kryzysu polityki. Należy do nich profesjonalizacja lub ekspertyzacja polityki. Na podstawie medialnego oglądu polityki demokratyczny przeciętny przedstawiciel ludu nabiera przekonania, że nie posiada zdolności i kompetencji do udziału w procesie decyzyjnym, wskutek czego całkowicie rezygnuje $\mathrm{z}$ udziału w niej. W przekonaniu tym wspierają go elity uznające ,prosty" lud za niedojrzały do sprawowania władzy. Winę za to ponoszą przede wszystkim zaniedbania edukacji, w tym edukacji kulturalnej. Wśród istniejących instytucji edukacyjnych najpotężniejsze pozostają instytucje religijne, które nie mają skłonności do wspierania demokratycznych form sprawowania władzy.

Przekazanie w trybie interpasywnym swojej politycznej sprawczości przez lud elitom sprawia, że sam lud przeobraża się w podmiot niepolityczny. Odpolitycznienie ludu demokratycznego, który, wybrawszy swoich reprezentantów, wychodzi poza politykę, aby skupić swoją uwagę na prywatności, jest z kolei odczytywane przez elity polityczne za sygnał, że one również mogą opuścić politykę i skupić się na posługiwaniu się mechanizmami politycznymi dla prywatnych interesów. Ostatecznie współczesne systemy polityczne, choć są udekorowane sztafażem demokracji, przeobrażają się w zbiór technik służących zarządzaniu tłumem i nie mają nic wspólnego $\mathrm{z}$ autentycznym demokratycznym współrządzeniem. Mamy więc do czynienia z atrofią demokracji.

W ten sposób działa mechanizm klasowej prywatyzacji polityki, zaś jedynym sposobem na jego ograniczanie jest ponowne wkroczenie ludu do polityki. Nowy populizm (Krastev, 2006) można wyjaśnić stwierdzając, że w pewnym momencie ktoś orientuje się, że polityka została pozostawiona sama sobie i głośno woła, aby zwrócić uwagę ludu demokratycznego, że nikt nie troszczy się o jego sprawy. Taką właśnie althusserowską interpelacją są radykalne ruchy w całej Europie. Interpelowany lud ożywia się w proteście, a następnie powierza swoje losy tym, którzy zwrócili jego uwagę. Na tym polega moment powrotu polityczności. Dodać należy, że lud budzi się co jakiś czas po to tylko, aby niebawem znowu zapaść w polityczną bierność.

\section{Epistokracja?}

Jak więc należy rozumieć sprawnie działającą demokrację? W świetle zaskakujących wyników wyborów demokratycznych w wielu różnych krajach w drugiej dekadzie XXI wieku, które stały się podstawą do formułowania diagnoz orzekających stan kryzysu demokracji, powyższe problemy teoretyczne uzyskały aktualny wymiar praktyczny. Tocząca się obecnie intensywna debata nad właściwym rozumieniem demokracji koncentruje się na próbach rozstrzygnięcia dylematu między ideą szerokiego uczestnictwa ludu w sprawowaniu władzy a ideałem deliberacyjnym, który zakłada, że władza w tych systemach winna być powierzona osobom dysponującym odpowiednimi kompetencjami poznawczymi. Obecna dyskusja w teorii demokracji koncentruje się więc na próbach rozstrzygnięcia dylematu między deliberacją i partycypacją. Projekty koncyliacyjne, starające się łączyć te dwa odmienne stanowiska, spotykają się z krytyką podkreślającą odmienność perspektyw deliberacyjnych i partycypacyjnych w teorii demokracji: są to stanowiska odmienne, które nie dają się pogodzić. Podstawą dla tej tezy jest kryterium kognitywne, odnoszące się do potencjału poznawczego członków wspólnoty politycz- 
nej. Uważa się również, że relacje między tymi modelami politycznymi mają charakter gry o sumie zerowej - im więcej partycypacji obywatelskiej, tym mniej miejsca na racjonalną debatę.

Stanowisko takie reprezentuje m.in. Janusz Grygieńć (2017). W swojej analizie modelu partycypacyjnego wskazuje on na argumenty wymierzone przeciwko inkluzywnemu modelowi Benjamina Barbera, który opiera się na pomyśle upowszechnienia deliberacji politycznych. Formułuje również tezę, że demokracja epistemiczna lub epistokracja, która stanowi specyficzną wersję modelu kognitokratycznego, jest stanowiskiem bardziej spójnym. Swoją argumentację wspiera przekonaniem, że nawet w przypadku niekompetencji decydentów politycznych nie zachodzi zagrożenie dla skutecznego działania demokratycznych systemów politycznych. Wiele miejsca poświęca także politycznej roli wiedzy specjalistycznej, którą określa mylącym anglicyzmem „ekspertyza”. W odpowiedzi na krytykę roli eksperckości w demokracji rozważa argumenty zwolenników demokracji asocjacyjnej oraz poliarchii bezpośrednio-deliberacyjnej i twierdzi, że oba te modele demokracji są oparte na przypisaniu wyróżnionej pozycji praktykom, którzy dysponują, jak się wyraża „ekspertyzą [tj. fachowością] kontrybucyjną”. Rozważa także konsekwencje modelu, w którym ekspertom, wyborcom oraz ich przedstawicielom przypisane są odmienne role $\mathrm{w}$ demokratycznym procesie decyzyjnym. Wyraża $\mathrm{w}$ nim preferencję na rzecz koncepcji „forów hybrydowych”, implikującej model decyzyjny, w którym „laicy” i „eksperci” są „umiejscowieni symetrycznie”, a swoją preferencję uzasadnia za pomocą idei „demokracji losowej”.

Z perspektywy przytoczonego na wstępie rozumienia demokracji jako „rządów ludu przez lud dla ludu", dylemat między partycypacją i deliberacją, który organizuje istotną część współczesnego dyskursu w teorii demokracji, można uznać za dylemat między pleonazmem a oksymoronem. Jeżeli bowiem demokracja to system polityczny polegający na rządach ludu, to termin "demokracja partycypacyjna” jest pleonazmem: nie ma bowiem rządów ludu bez udziału ludu w rządzeniu. „Demokracja deliberacyjna” z kolei, zwłaszcza w rozumieniu epistokratycznym, opartym na sztywnej opozycji między elitą kognitariuszy a masami ignorantów, odmawia ludowi udziału we władzy, ponieważ odmawia mu kompetencji rzekomo niezbędnych do udziału w sprawowaniu władzy, okazuje się elitystycznym zanegowaniem demokracji. To ostatnie rozumienie demokracji opiera się na fałszywym założeniu, że ci, którzy mają wiedzę, są obdarzeni zdolnościami sprawowania władzy, ci zaś, którzy jej nie posiadają, z definicji są przeznaczeni do poddaństwa. Takie rozwiązanie dylematu między deliberacją i partycypacją przechyla się mocno na stronę modelu elitarnego, deliberacyjnego, epistokratycznego lub kognitokratycznego.

Stanowisko to należy uznać za problematyczne z wielu powodów, spośród których wymienię kilka. Po pierwsze, opiera się ono nie tylko na założeniu, że prawo do udziału we władzy jest pochodną posiadanej wiedzy; w istocie można powiedzieć mocniej: posiadana wiedza jest uprawomocnieniem do udziału we władzy. Opiera się ono także na założeniu, że sama demokracja jako system polityczny wymaga uzasadnienia epistemologicznego. Uważam, że oba te założenie są kwestionowalne i obciążone błędem, który można określić mianem błędu kognitokratycznego. Poniżej formułuję szereg argumentów polemicznych z tym stanowiskiem.

Jak wskazałem powyżej, idealny typ demokracji zakłada, że demokracja nie potrzebuje uzasadnienia. Można więc postawić pytanie, czy potrzebuje ona uzasadnienia epi- 
stemologicznego? Wydaje się, że wstępnie zarysowany normatywny ideał demokracji nie odwołuje się do uzasadnień epistemologicznych, lecz etycznych: znajduje on uzasadnienie $\mathrm{w}$ silnych założenia moralnych o charakterze egalitarnym, przyznających jednostkom prawo do udziału w zarządzaniu wspólnotą, do której należą. Wśród argumentów na rzecz szerokiego udziału w władzy politycznej ważkie są m.in. tezy Jamesa Surowieckiego oraz innych „partycypacjonistów”. Przy okazji wzmianki o koncepcji mądrości tłumu Surowieckiego należy jednak wspomnieć, że nawet jego inkluzywne stanowisko również ma charakter epistokratyczny, albowiem kwestionując skuteczność i korzystność decyzji podejmowanych przez ekskluzywne kompetentne epistokratyczne elity, Surowiecki opowiada się za szeroką partycypacją, która według niego generuje synergiczny efekt mądrości, jakiej nie są w stanie, mimo swojej wiedzy specjalistycznej, wytworzyć eksperckie elity. Koncepcja Surowieckiego więc również jest kognitokratyczna, choć egalitarna, albowiem wiedzę niezbędną do zarządzania wspólnotą polityczną lokuje po stronie ludu, nie zaś elit. Surowiecki pisze np.: ,sensem demokracji przedstawicielskiej jest to, że umożliwia ona na ten sam rodzaj poznawczego podziału pracy, który funkcjonuje w pozostałej części społeczeństwa" (Surowiecki, 2005, s. 266), co potwierdza jego kognitokratyczne skłonności, a zarazem, mimo swych inkluzywnych argumentów, poświadcza wiarę w nieuchronność demokracji przedstawicielskiej.

Jednym $z$ argumentów na rzecz modelu epistokratycznego w wersji elitarnej jest to, że jest mniej szkodliwy dla skuteczności demokracji. Argument ten jest zaskakujący, ponieważ skłania bowiem do postawienia pytania o powody, dla których należałoby powierzać władzę w systemach demokratycznych fachowcom, skoro mogą okazywać się niekompetentni; należy rozumieć, jak sądzę, że ich szkodliwość jest mniejsza w porównaniu ze szkodami wyrządzanymi wspólnocie politycznej przez należący do niej lud. Twierdzenie, że niekompetencja fachowców nie wyrządza szczególnych szkód wspólnocie politycznej, którą zarządzają, nie jest ani dobrą, ani wystarczającą legitymizacją dla powierzenia im władzy. Teza o mniejszej szkodliwości niekompetencji elit politycznych jest bardzo słabym wsparciem dla tezy na rzecz demokracji kognitokratycznej, a ponadto jest ona nie tylko kontrowersyjna: można przytoczyć liczne przykłady na rzecz jej falsyfikacji.

To prowadzi do kolejnego zagadnienia, które nasuwa poważną, a być może najważniejszą wątpliwość. Trudno bowiem znaleźć rzetelną definicję wiedzy specjalistycznej, fachowości lub kompetencji, która mogłaby w sposób niebudzący wątpliwości stanowić legitymację do sprawowania władzy $\mathrm{w}$ demokracji. Jedną z charakterystyk dookreślających fachowość, która jest niezbędna w polityce i która stanowi kryterium uznania jej za ważniejszą od opinii obywateli, jest uznanie, że wartość fachowości eksperckiej lub wiedzy specjalistycznej polega nie na szerokości wiedzy, lecz na „wyjątkowości” perspektywy. W większości odniesień do tak rozumianej „wiedzy specjalistycznej” ma się na myśli wiedzę naukową, na przykład z zakresu genetyki, biotechnologii, inżynierii, atomistyki, itd. W tej sprawie należy powiedzieć, że teza, iż wiedza specjalistyczna jest potrzebna w zarządzaniu wspólnotą polityczną, jest banałem. Natomiast przyznanie wiedzy specjalistycznej decydującej roli w polityce, na tyle decydującej, aby ograniczać udział ludu w rządzeniu wspólnotą, która ów lud konstytuuje, nie jest banałem, lecz jest twierdzeniem co najmniej dyskusyjnym. Aby to spróbować wykazać, do licznych argumentów przeciwko elitarnym koncepcjom epistokratycznym chciałbym dorzucić 
jeszcze kilka, co uczynię za pomocą ektetycznego odwołania się do problematycznego statusu wiedzy przypisywanej ekspertom.

Po pierwsze, doskonale znane jest, także w Polsce, zjawisko „ekspertyzacji”, czy wręcz ,profesoryzacji” polityki. Zdawałoby się, że trudno o bardziej ugruntowane poświadczenie fachowości, kompetencji czy eksperckości niż formalny status profesora, na przykład nauk społecznych czy politycznych. Zarazem jednak doskonale wiadomo, że profesorskość nie jest wystarczającym znamieniem fachowości politycznej. Bismarckowi przypisywane jest znane zawołanie w odniesieniu do pracy parlamentu hanowerskiego: achtundachtzig Professoren: Vaterland, du bist verloren! To stwierdzenie uzyskało status powszechnej mądrości sugerującej wstrzemięźliwość w przypisywaniu roli politycznej kompetencjom poznawczym. Znane są przykłady ustrojów, w których gromady profesorów potulnie stawiają się na służbę dyktatorskiego reżimu kierowanego przez człowieka pozbawionego formalnie poświadczonych kompetencji i fachowości, lecz posiadającego zdolność, która chciałbym tu określić mianem umiejętności politycznej, lub też na służbę kapitału. W obu przypadkach czynią to w nadziei na uszczknięcie dla siebie pewnych dóbr - dóbr uznania lub dóbr materialnych, lub jednych i drugich. Stawia to problem nieobiektywności i nieuczciwości ekspertów. Jest rzeczą oczywistą, że problem ten dotyka także najbardziej eksperckich z ekspertów i stanowi mocny argument przeciwko epistokracji.

Ten antyelitarny argument można dodatkowo wzmocnić za pomocą odwołania do znanego traktatu filozoficznego Douglasa Adamsa (1987, s. 153-155), w którym autor ten twierdzi, że specjalistyczna wiedza na temat praw fizycznych Newtona, czy nawet Einsteina, nie przekłada się na umiejętność chwytania piłki. Przenosząc to spostrzeżenie na sferę polityki można powiedzieć, że poświadczona znajomość praw polityki i społeczeństwa nie przekłada się na umiejętne polityczne zarządzanie społeczeństwami; podręczniki historii politycznej wskazują na niejeden przykład niebezpieczeństw, do jakich prowadzi w polityce doktrynerstwo, zwłaszcza doktrynerstwo zadufanych elit.

Kolejny argument przeciwko modelowi epistokratycznemu kwestionuje zarówno w założenie o niezbędności wiedzy do udziału w polityce, jak i w założenie o konieczności uprawomocnienia demokracji. Chodzi mianowicie o to, że zwolennicy stanowisk epistokratycznych nie przykładają dostatecznie dużo wagi do faktu, że nierówność w kompetencjach i wiedzy specjalistycznej, uznawanych za warunek sine qua non udziału we władzy, jest zazwyczaj pochodną nierówności statusu społecznego i politycznego, oraz do tego, że demokracja powstała właśnie po to, aby te nierówności zwalczać i znosić, a przynajmniej łagodzić. $Z$ punktu widzenia tego argumentu, system epistokratyczny okazuje się antydemokratyczny, ponieważ, po pierwsze, żeruje na nierównościach społecznych, po drugie zaś, sprzyja utrwalaniu owych nierówności, które były przyczyną powstawania systemów i ruchów demokratycznych; jest więc również problematyczny etycznie.

Poważne wątpliwości budzi pomijanie przez deliberacjonistów właśnie pozakognitywnych aspektów sprawowania władzy. Chodzi tu w szczególności o specyficzne rozumienie emocji w polityce. Emocjonalność ludzka jest z definicji postrzegana jako irracjonalna, a więc szkodliwa, jest czymś, co w polityce wadzi, przeszkadza i należy ją poskramiać i represjonować. Wydaje się, że przeoczeniu ulega tu fakt, że w polityce emocjonalność wypierana i represjonowana ma tendencje do powracania w sposób 
gwałtowny i burzliwy. Przeoczanie i lekceważenie „zmiennej emocjonalnej” (Ost, 2007; Chmielewski, 2009), by posłużyć się znanym terminem politologicznym, w praktyce politycznej zazwyczaj srogo się mści, zaś w teorii polityki daje jej obraz niepełny i nieokaleczony. Obraz polityki, który pomija emocjonalny wymiar życia społecznego, będzie z konieczności niepełny i okaleczony, ponieważ opiera się na okaleczonej antropologii filozoficznej, według których emocje są pobocznym i jak gdyby niekoniecznym aspektem człowieczeństwa.

Z tym zagadnieniem ściśle wiąże się problematyczne rozumienie partycypacji politycznej jako działalności zorganizowanej i uregulowanej. Należy pamiętać o istotnej kategorii radykalnej demokracji agonistycznej, która obejmuje działania polityczne niepoddające się regularyzacji. Nie mam tu na myśli agonizmu w salonowym wydaniu Isaiaha Berlina i Johna Graya (Gray, 1995), którzy mają na myśli zasadniczo nierozstrzygalność sporów moralnych i politycznych. Chodzi mi o ten rodzaj demokracji agonistycznej, o jakiej pisał m.in. klasyk angielskiej myśli politycznej Adam Ferguson, prekursor mocnej demokracji kontestacyjnej, i która obejmuje działania gwałtowne, a nawet sięgające po przemoc, a więc takie formy partycypacji politycznej, jak demonstracje, strajki, zamieszki, powstania zbrojne itd. (Ferguson, 1995, s. 63-64).

Teza o rozdzielności „partycypacji” i „deliberacji”, jest problematyczna także ze względu na to, że zakłada ona sztywne rozdzielenie obywateli na cognoscendi i indocti, Rozróżnienie rozpada się całkowicie z punktu widzenia odmiennej antropologii filozoficzno-politycznej, która odrzuca perspektywę kognitokratyczną i która przypisuje rolę polityczną nie tylko wiedzy, ale także zazwyczaj lekceważonym emocjom oraz intuicjom, a nade wszystko zdolnościom moralnym jednostek.

Należy wspomnieć o jeszcze jednym problemie, przed którym staje każda koncepcja kognitokratyczna. Edmund Burke, wybitny teoretyk polityki i bardzo doświadczony jej praktyk, napisał, że nigdy nie spotkał się z planem, który nie zostałby poprawiony dzięki spostrzeżeniom tych, którzy stali o wiele niżej pod względem możliwości intelektualnych od osoby, która przewodziła pracy (Popper, 1993, t. I, s. 13). Jeszcze starszy autorytet polityczny, Perykles, powiedział, że choć tylko niewielu może tworzyć politykę, każdy jest zdolny ją oceniać (Tukidydes, 1957, II, s. 37-41). Te dwa zapisy doświadczeń praktykujących polityków nasuwają myśl, że kognitokracja jako projekt polityczny jest fundamentalnie wadliwy. Albowiem w polityce rolę odgrywa nie tylko wiedza, ale także emocje, intuicje, zdolności moralne i wyobraźnia. Stwierdzenie to może się stać punktem wyjścia do diagnozy kryzysu współczesnych demokracji. Można więc powiedzieć, iż kryzys demokracji jest wynikiem nie braku wiedzy po stronie ludu, nie jest on także skutkiem problematycznych kompetencji i wadliwej wiedzy specjalistycznej ekspertów, nie jest też pochodną problemów w skutecznym zarządzaniu wiedzą. Kryzysu demokracji nie można zrozumieć bez uwzględnienia siły emocji, niedyskursywnych intuicji oraz silnych ocen moralnych obywateli, zarówno po stronie rządzonych, jak i rządzących. Źródłem kryzysu jest podatność emocji i ocen moralnych na sterowanie ku realizacji celów, które są moralnie niewłaściwe. W sterowaniu emocjonalnością i moralnością niezbędna jest więc nie tylko wiedza specjalistyczna, lecz umiejętność, którą określiłem powyżej mianem politycznej. Fundamentalnym problemem demokracji nie jest więc niewłaściwe zarządzanie wiedzą, lecz niewłaściwe moralnie zarządzanie ludzkim emocjami, zaś jej słabym punktem jest to, że ludzkimi emocjami najłatwiej jest zarządzać 
za pomocą emocji strachu i lęku oraz za pomocą wskazywania realnego lub fikcyjnego wroga. Z tej racji kognitokratyzm nie może sobie rościć pretensji do roli całościowego rozwiązania dla kryzysu demokracji, stanowi bowiem co najwyżej technokratyczne rozwiązanie cząstkowego problemu, które w przypadku wdrożenia może pewne problemy rozwiązywać, lecz także może stwarzać problemy poważniejsze, niż te, które jest w stanie rozwiązać.

Debatę między deliberacjonizmem i partycypacjonizmem warto dopełnić kilkoma uwagami o naturze historycznej. Można pokusić się o hipotezę, że ta opozycja ukształtowała się wraz z narodzinami demokracji. Świadczą o tym przytoczone na wstępie stanowiska starożytnych myślicieli. Kwestia ta była naturalnie przedmiotem uwagi wielu późniejszych myślicieli politycznych. W XIX wieku Francis Lieber skonceptualizował opozycję między deliberacją i partycypacją za pomocą przeciwstawienia dwóch tradycji politycznych, „gallikańskej” i ,anglikańskiej” (Hayek, 1978, s. 5). Pierwsza stanowi prefigurację epistokratycznych idei deliberacyjnych, druga zaś idei partycypacyjnych. Spór ten daje o sobie znać także w pismach politycznych J. S. Milla i Josepha Schumpetera, zaś współcześnie przede wszystkim w znanym eseju F. A. Hayeka, zawierającego interesujący projekt polityczny, zgodnie z którym dobry system polityczny miałby być kierowany przez zgromadzenie złożone z osób wybieranych na piętnastoletnią kadencję. Wiek biernego prawa wyborczego Hayek ustalił na 45 lat, a po wygaśnięciu mandatu wybranych osób w wieku 60 lat, miałyby one gwarancję kolejnych 10 lat pracy na godnych stanowiskach. Każdego roku wybierano by jedną piątą członków zgromadzenia, zaś każdy obywatel mógłby głosować jeden (sic!) raz w 45 roku życia na jednego ze swych rówieśników. Pomysł Hayeka jest odpowiedzialny za ukształtowanie się tendencji antyegalitarnych na gruncie liberalizmu. Jakkolwiek można odnieść się do tego projektu bardzo krytycznie, to jego autorowi nie można zarzucić niewrażliwości na pozakognitywne aspekty rządzenia wspólnotą polityczną, która jest cechą większości koncepcji epistokratycznych (Hayek, 1978, s 152-162).

Kryzys demokracji w nieuchronny sposób znajduje odzwierciedlenie w świadomości publicznej, jest również rejestrowany przez elity literackie i artystyczne, które w swoim nieskrępowaniu formułują rozmaite projekty sanacyjne. Isaac Asimov zaproponował pomysł rządzenia przez przeciętnego Amerykanina wyłonionego do sprawowania władzy za pomocą analizy przeprowadzonej przez komputer Multivac po to, aby cała reszta społeczeństwa nie musiała się fatygować do wyborów (Asimov, 1990). Takie pomysły wykroczyły już dawno poza ramy powieści literackie i były realizowane, chociaż jak dotąd tylko w stylu działań artystyczno-politycznych upowszechnionych przez ruch sytuacjonistyczny w wielu krajach, w tym m.in. we Francji, USA, ale także w Polsce. W kampanii prezydenckiej w 2000 roku spore zamieszanie wywołała kandydatura Wiktorii Cukt, kandydatki stworzonej przez grupę artystyczną. Stworzona kandydatka miała status nie realnej postaci, lecz wirtualnego narzędzia decydującego; decyzje podejmowane przez tę kandydatkę miały wyrażać wolę ludu, zaś lud miałby uczestniczyć w kształtowaniu decyzji prezydenckich w trybie ciągłym, za pomocą opowiadania się za poszczególnymi rozwiązaniami przez klikanie na odpowiednie ikony na portalu stanowiącym wirtualną rezydencję Prezydent Wiktorii Cukt. W wyborach w 2015 roku zaś podobną rolę odegrała fikcyjna kandydatka Paulina Macutkiewicz. Wśród kandydatów tego typu w USA znaleźli się m.in. Kubuś Puchatek, Harry Potter oraz Lord Voldemort, kandydujący na 
stanowisko wiceprezydenta u boku Sary Palin. Te artystyczno-polityczne akcje i demonstracje są tyleż znakiem publicznej świadomości niedoskonałości w funkcjonowaniu współczesnych demokracji, co dowodem bezradności społecznej wobec jej schorzeń, albowiem skuteczność tych interwencji w usuwaniu owych niedoskonałości i ich korekcie jest znikoma. Ich ważka rola polega na tym, że służą one przypominaniu o doniosłości problemów w sprawowaniu władzy ludowi, a także teoretykom demokracji, co czynią w sposób pokojowy, nierewolucyjny, a więc społecznie niekosztowny.

\section{Podsumowanie}

Demokratycznego sprawowania władzy nie można zredukować do problemów poznawczych. Postrzeganie problemów w sprawowaniu władzy w demokracjach z perspektywy dylematu między specjalistyczną deliberacją ekspercką a powszechnym udziałem ludu w procesie podejmowania decyzji politycznych prowadzi w ślepą uliczkę kognitokratyzmu. Źródeł tej postawy w jej elitarnej wersji należy poszukiwać w Platońskiej teorii politycznej, proto-scientystycznej ideologii Francisa Bacona oraz w rozległej literaturze utopijnej, opartej na przekonaniu, że wiedza naukowa może okazać się fundamentem i gwarantem powszechnego szczęścia społeczeństw zamieszkujących naukowo urządzone republiki. Elitarną wersję kognitokracji można interpretować jako neo-postpozytywistyczne residuum archaicznego przesądu, że wiedza jest władzą, przy czym, mimo ideologicznego upodobania do wiedzy naukowej, zwolennicy tej wersji kognitokratyzmu zazwyczaj nie oferują nawet rzetelnej definicji wiedzy, jaką uznają za sine qua non dobrej polityki.

Wyjście z tego impasu polega na uświadomieniu sobie, że każde sprawowanie władzy polega na podejmowaniu decyzji i ich realizacji. Demokratyczne sprawowanie władzy polega na kolektywnym procesie podejmowania decyzji i na społecznej organizacji ich wdrażania w życie. W obu przypadkach kompetencje poznawcze i poleganie na wiedzy naukowej są niezbędne. Nie mniej istotne jest jednak to, co można określić umiejętnością polityczną. Ponieważ polityka jest przedsięwzięciem moralnym, istotną częścią tego, co nazywam umiejętnością polityczną, są kompetencje moralne. Implikują one w szczególności świadomość obowiązków sprawiedliwości oraz zobowiązań wynikających z odpowiedzialności. Zwiększanie kompetencji poznawczych obywateli demokratycznego społeczeństwa może służyć rozwiązywaniu problemów demokracji, jednak upowszechnianie kompetencji moralnych, zwłaszcza poczucia odpowiedzialności za losy swojej wspólnoty, służy temu celowi w większym stopniu. Autentycznie demokratyczny system polityczny jest możliwy o tyle, o ile opiera się na fundamencie powszechnego poczucia odpowiedzialności za wspólnotę polityczną, stanowiącego element świadomości każdego obywatela. Nie mniej istotną częścią umiejętności politycznej są kompetencje emocjonalne, obejmujące w szczególności wrażliwość na kondycję jednostek i całego społeczeństwa. To z kolei wymaga zdolności wyobraźni, stanowiącej integralną część kompetencji estetycznej ${ }^{1}$.

${ }^{1}$ Odnosząc swoje postulaty do sfery obywatelskości demokratycznej, nie zaś kwestii demokratycznego sprawowania władzy, K. Dziubka definiuje obywatelskość jako „habitualną, trwałą dyspozycję mentalną, moralną i emocjonalną podmiotu politycznego do wyborów i decyzji zorientowanych na 
Tak rozumiana umiejętność polityczna ma swoje liczne i rozmaite prefiguracje historyczne. Jedną z nich jest Arystotelesowska koncepcja roztropności, inną - Machiavellego doktryna virtù, współcześnie trwają próby sformułowania alternatywnego pojęcia cnoty politycznej jako przymiotu władzy politycznej. Znajdują się wśród nich koncepcje inspirowane twórczością Alasdaira MacIntyre’a (2008, s. 3-7). Współczesny kryzys demokracji, zwłaszcza kryzys przywództwa demokratycznego oraz metod wyłaniania przywódców w systemach demokratycznych unaocznia, że zdefiniowanie umiejętności politycznej na nowo jest zadaniem teoretycznie aktualnym i praktycznie pilnym. Punktem wyjścia tych dociekań winna się stać świadomość, że normatywny ideał demokracji inkluzywnej opiera się na przesłance o potencjalnie powszechnej zdolności do kształtowania umiejętności politycznej oraz na przekonaniu, że owa potencjalność może ulegać aktualizacji w samym procesie aktywności politycznej.

\section{Bibliografia}

Adams D. (1987), Dirk Gently's Holistic Detective Agency, Gallery Books New York.

Bobbio N. (1998), Liberalizm i demokracja, przekł. P. Bravo, Znak - Fundacja im. Stefana Batorego, Kraków-Warszawa.

Böckenförde E.-W. (1976), Staat, Gesellschaft, Freiheit, Suhrkamp, Frankfurt.

Boetie E. de la (1975), The Discourse of Voluntary Servitude, trans. H. Kurz, The Mises Institute, Auburn, Alabama.

Chmielewski A. (2005), Dwie koncepcje jedności. Interwencje filozoficzno-polityczne, Oficyna Branta, Bydgoszcz-Wrocław.

Chmielewski A., Psychopatologia życia politycznego. Podręcznik ilustrowany, Oficyna Wydawnicza Atut, Wrocław 2009.

Dziubka K. (2008), Obywatelskość jako virtú podmiotu demokracji, Wydawnictwo Uniwersytetu Wrocławskiego, Wrocław.

Ferguson A. (1995), An Essay on the History of Civil Society, red. F. Oz-Salberger, Cambridge University Press.

Gajda J. (1986), Prawo natury i umowa spoleczna w filozofii przedsokratejskiej, Wydawnictwo Uniwersytetu Wrocławskiego, Wrocław.

Gray J. (1995), Isaiah Berlin: An Interpretation of His Thought, HarperCollins.

Grygieńć J. (2017), Demokracja na rozdrożu. Deliberacja czy partycypacja polityczna?, Universitas, Kraków.

Hayek F. A. von (1978), Errors of Constructivism, w: New Studies in Philosophy, Politics, Economics and the History of Ideas, Routledge and Kegan Paul, London.

Hayek F. A. von (1978), Whither Democracy, w: New Studies in Philosophy, Politics, Economy and the History of Ideas, Routledge and Kegan Paul, London.

Krastev I. (2006), The new Europe: respectable populism, clockwork liberalism, „Open Democracy”, 21 March.

Lasch C. (1997), Bunt elit, przekł., D. Rodziewicz, Platan, Kraków.

Lincoln A. (1998), Gettysburg Address, w: Speeches that Changed the World, HarperCollins, New York.

realizację dóbr publicznych, umożliwiających efektywny przebieg procesów politycznych w porządkach demokratycznych" (Dziubka, 2008, s. 13). 
MacIntyre A. (2008), How Aristotelianism Can Become Revolutionary: Ethics, Resistance, and Utopia, „Philosophy of Management”, vol. 7, nr 1, ss. 3-7.

Ost D. (2007), Klęska „Solidarności”. Gniew i polityka w postkomunistycznej Europie, przekł. H. Jankowska, Warszawskie Wydawnictwo Literackie Muza S. A., Warszawa.

Popper K. (1993), Spoleczeństwo otwarte i jego wrogowie, PWN, Warszawa.

Rousseau J.-J. (2002), Umowa społeczna, przekł. A. Peretiatkowicz, Antyk, Kęty.

Strauss L. (1987), Plato, w: L. Strauss, J. Cropsey, History of Political Philosophy, The University of Chicago Press, Chicago-London.

Surowiecki J. (2005), The wisdom of crowds: why the many are smarter than the few and how collective wisdom shapes business, economies, societies, and nations, Random House, New York.

Swenson K. (2018), Rebekah Mercer, the billionaire backer of Bannon and Trump, chooses sides, "The Washington Post," Jan. 5, https://www.washingtonpost.com/news/morning-mix/ wp/2018/01/05/rebekah-mercer-the-billionaire-backer-of-bannon-and-trump-choosessides/?utm_term=.05dca59279d5, 25 maja 2018.

Tukidydes (1957), Wojna peloponeska, przekł. K. Kumaniecki, Czytelnik.

Žižek S. (2001), Przekleństwo fantazji, przekł. A. Chmielewski, Wydawnictwo Uniwersytetu Wrocławskiego.

\title{
The role of cognitive competences in democratic political systems
}

\begin{abstract}
Summary
Taking as the starting the normative ideal of democracy, grounded in an inclusive understanding of the subject point of democracy, the author argues that various concepts of democracy assign particularly important role to cognitive competences and see it as an exclusive entitlement to participate in the exercise of political power in democratic systems. The case in point is contemporary debate on the proper understanding of democracy which focuses on the dilemma between, on the one hand, the idea of broad participation of the people in the democratic governance, and, on the other, the deliberative ideal which presupposes that power in these systems should be entrusted only to people with appropriate cognitive competences. The author analyzes the main elements of "cognitocratic" or "epistocratic" conceptions and points out to potential perils resulting from the attribution of a prominent role in the theory of democracy to cognitive competences. In opposition to cognitocratic approaches, both in their universalist and elite versions, the author argues that a more adequate understanding of governance in democratic systems should instead be based on the wider category of political ability. He also claims that a novel definition of this category should be informed by the normative ideal of democracy which is based on the recognition of potentially universal capabilities to develop the political ability and that this potential may in fact be activated through the actual participation in democratic politics.
\end{abstract}

Key words: democracy, knowledge, power, epistocracy, political ability 